\title{
DESIGN AND VALIDATION OF THEMATIC E-MODULES: OPTIMIZATION OF PROBLEM-BASED LEARNING
}

\author{
Submitted: \\ 9 November 2021 \\ Accepted: \\ 5 Desember 2021 \\ Published: \\ 31 Januari 2022
}

\author{
Denna Delawanti Chrisyarani*1, Prihatin Sulistyowati ${ }^{2}$. \\ nnadelawanti@unikama.ac.id ${ }^{1}$, prihatinsulistyowati@unikama.ac.id ${ }^{2}$ \\ PGSD, FIP, Universitas PGRI Kanjuruhan Malang ${ }^{1}$ \\ PGSD, FIP, Universitas PGRI Kanjuruhan Malang ${ }^{2}$ \\ *Corresponding Author
}

\begin{abstract}
Preparing for learning well is the teacher's obligation, especially in this COVID-19 pandemic. One thing that needs to be considered is compiling appropriate teaching materials. The purpose of this research is to design and validate the thematic emodule design and material based on problem-solving for 3rd-grade elementary school students. This research design used the Borg \& Gall development model. The stages are: (1) initial study and collecting data, (2) creating an activity framework, (3) developing product drafts, (4) validation tests, (5) revising validation results. The research instrument is a content and design validation questionnaire. The results of this research are problem-solving-based thematic e-modules. The module presentation was systematic consists of Mapping Basic Competencies, Mapping Indicators, Learning Objectives, Let's Read, Let's Tell a Story, Let's Observe, Let's Discuss, Let's Write, Let's Practice, Conclusion. The results of material validation are $93 \%$ in the very valid category and $91 \%$ of media validation results are very valid categories so that they can be used in learning.
\end{abstract}

Keywords: e-module, thematic, problem-solving.

\section{INTRODUCTION}

Thematic learning is learning formed from themes and is related to the student's real-life/contextual (Akbar \& Sutama, 2010; Utari, Degeng, \& Akbar, 2016). Regarding contextual learning, the professional task of a teacher is to make learning more interesting, easier, and meaningful. So that teachers need to prepare to learn well, such as: determining teaching objectives, subjects to be taught, teaching models, teaching methods, the subject matter in student modules, teaching aids, and evaluation techniques used(Chrisyarani \& Akbar, 2017).

Preparing for learning well is the teacher's obligation, especially during this Covid-19 era. The impact of Covid-19 in education has led to the widespread closure of schools. UNESCO recommends using online learning as well as using platforms to aid learning(Caskurlu, Richardson, Maeda, \& Kozan, 2021; UNESCO, 
2020). Based on this policy, the Ministry of Education and Culture participates in making policies in solving learning problems during the COVID-19 pandemic at the education unit level. (Hong, Lee, \& Ye, 2021; Ministry of Education and Culture, 2020).

This is also felt by teachers at elementary schools in Malang City. Based on the interview results that have been conducted, there are obstacles in implementing learning during this covid-19 pandemic. Changes in learning from face-to-face to online, inadequate preparation in compiling online teaching materials. Thus, teaching materials still use printed teaching materials, difficulties in monitoring student learning as a whole. The application of methods, models, and media is also limited. Based on interview results conducted, problems obtained were related to the teaching materials used were still printed, difficulties in applying models, and learning methods in online learning.

Similar research that has been carried out is about the views of teachers regarding learning during the COVID-19 pandemic (Vu et al., 2020). E-module Development(Erick Suryadi, Agustini, \& Sugihartini, 2019; Sugihartini \& Jayanta, 2017). Module development is based on problem-solving and the use of technology(Kurniawan, 2019; Troseth \& Strouse, 2017).

The purpose of this research is to design and validate problem-solving-based thematic e-modules in thematic learning. Through e-modules students will be trained to learn independently(Mudiono, Akbar, Dwi Yasa, \& Delawanti Chrisyarani, 2017). The advantages of e-modules lie in solving problems in learning, problem orientation, organizing students in learning, assisting in collecting data individually or in groups, developing and presenting data, and leading to the problem-solving process.(Montag-Smit \& Maertz, 2017; Munir, Baroutian, Young, \& Carter, 2018). Problem-solving models help students observe relationships, problems solving and infer the concepts learned(de Hei, Strijbos, Sjoer, \& Admiraal, 2016; Goyena \& Fallis, 2019; Kurniawan, 2019). Through the design and validation process of this problem-solving-based e-module, it is hoped that it can help students in thematic learning to make it more meaningful so that it can be applied in real life. 


\section{METHOD}

Development of thematic e-modules based on Problem Solving using the Borg $\&$ Gall model. The development steps carried out only reached the 5th stage (product revision). Its flow is as follows: (1) initial study and collecting data, (2) creating an activity framework, (3) developing product drafts, (4) validation tests, (5) revising validation results. The subjects in this study were content/material experts, media experts. The instrument of this research is a questionnaire. The analysis technique is qualitative and quantitative. Qualitative data were obtained from comments from content experts and media experts. Quantitative data was obtained through the value of the questionnaire.

The results of validation questionnaires then were analyzed. The formula for validation gain was adapted with the following modifications(Akbar \& Sutama, 2010):

$V m=\frac{T S e}{T S h} \times 100 \% \quad V d=\frac{T S e}{T S h} \times 100 \% \quad V t=\frac{V m+V d}{2}=\cdots \%$

Information:

$\begin{array}{ll}\mathrm{Vm} & =\text { Validity content } / \text { material } \\ \mathrm{Vd} & =\text { Validity design } \\ \mathrm{Vt} & =\text { Total Score achieved } \\ \mathrm{TSh} & =\text { Total score } \\ \mathrm{Vt} & =\text { Total validation }\end{array}$

$100 \%$

Table 1. Criteria for the validity of the Thematic e-Module Based on Problem Solving

\begin{tabular}{llll}
\hline $\begin{array}{l}\text { No. } \\
\text { Attractiveness } \\
\text { Score }\end{array}$ & Practicality level & Validity level \\
\hline 1. & $86 \%-100 \%$ & $\begin{array}{l}\text { Practicality is very good, no revision is Very Valid (no revision) } \\
\text { needed }\end{array}$ & \\
\hline 2. & $70 \%-85 \%$ & Practicality is good, no revision is needed & quite Valid (with revision) \\
\hline 3. & $60 \%-69 \%$ & Practicality is enough, need minor revision & Invalid (unusable) \\
\hline 4. & $0 \%-59 \%$ & Less practicality, total revision & very invalid \\
\hline
\end{tabular}




\section{RESULTS}

The results of this development research are in form of problem-solving-based thematic e-modules. Systematic module presentation was consisted of Mapping Basic Competencies, Mapping Indicators, Learning Objectives, Let's Read, Let's Tell a Story, Let's Observe, Let's Discuss, Let's Write, Let's Practice, Conclusions, test questions. The following presents components in the module.

Table 2. Components of problem solving-based thematic e-modules

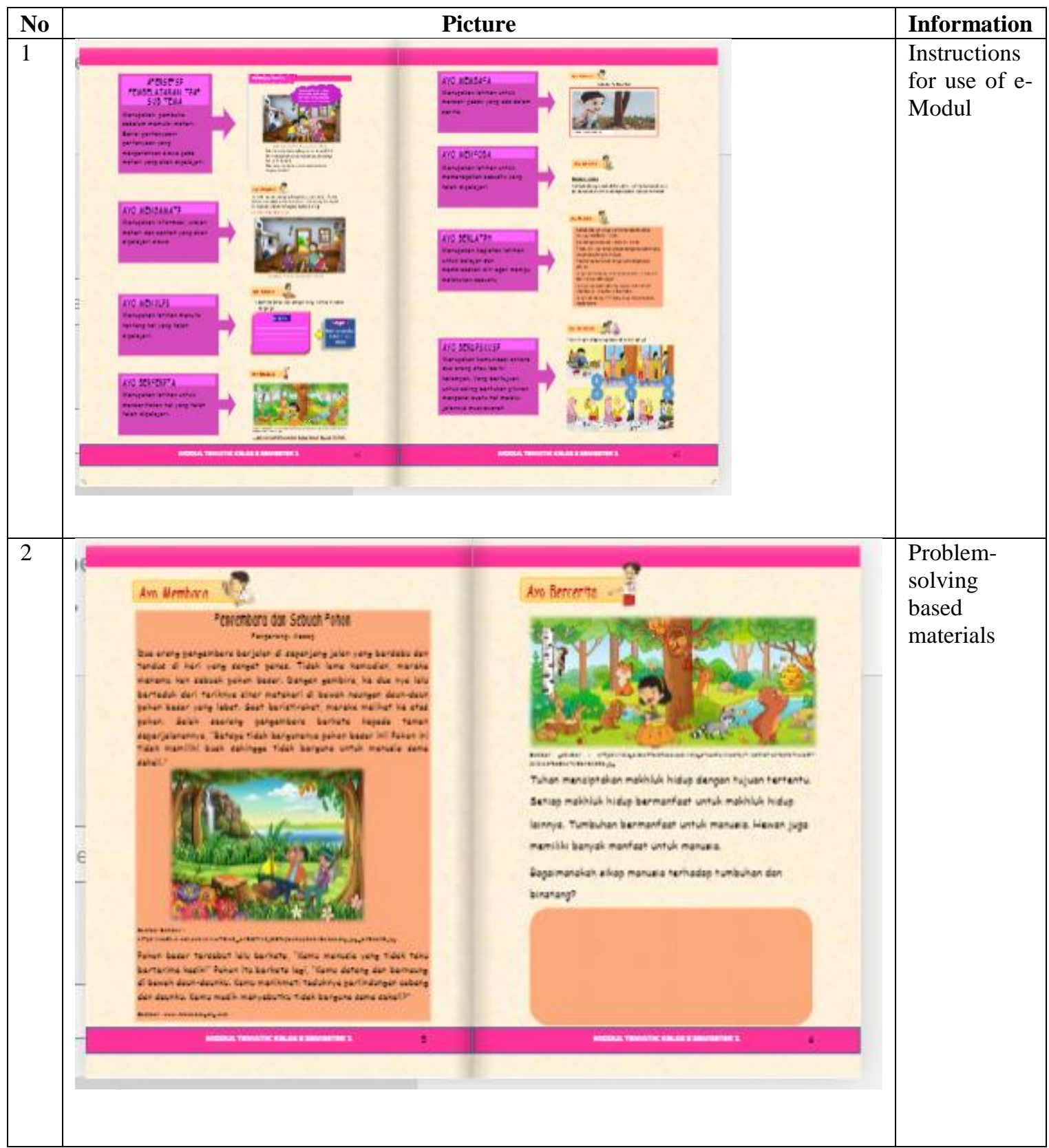




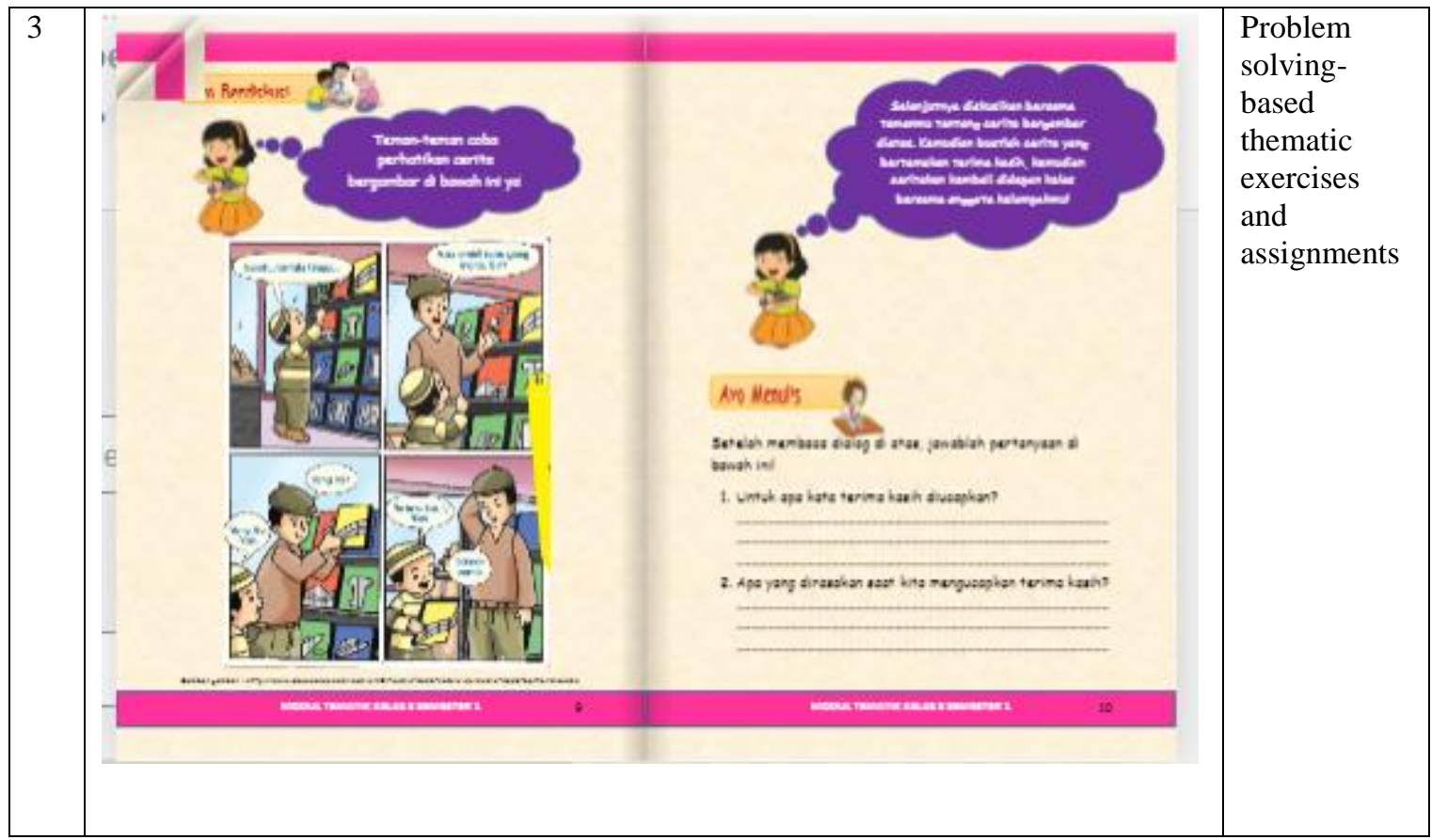

Product validity analysis is carried out by experts who are considered by predetermined criteria to test the theoretical suitability of the product. Validation data of the e-module product was obtained through a validation questionnaire. Validation results from the material experts got a percentage of $93 \%$ and received qualitative input as contained in table 3 below.

Table 3. Suggestions from Material Experts and Revisions made

\begin{tabular}{ccccc}
\hline No & Part & \multicolumn{2}{c}{ Before Revision } & After revision \\
\hline 1 & Student Module & $\begin{array}{c}\text { 1. Need to add } \\
\text { conclusion }\end{array}$ & a & $\begin{array}{c}\text { Conclusion activities } \\
\text { have been added }\end{array}$ \\
\hline
\end{tabular}

The validation results from the design experts got a percentage of $91 \%$ and received qualitative input which is contained in table 4 below.

Table 4. Qualitative Data Validation Aspects of Module Design

\begin{tabular}{cccc}
\hline No & Part & Before Revision & After revision \\
\hline 1 & $\begin{array}{c}\text { Student } \\
\text { Module }\end{array}$ & $\begin{array}{c}\text { 1. Pay attention to the } \\
\text { choice of font color } \\
\text { used }\end{array}$ & $\begin{array}{c}\text { Use easy-to-read font } \\
\text { colors }\end{array}$ \\
\hline
\end{tabular}

The total validation of problem-solving-based thematic e-modules can be seen in Table 5 below. 
Table 5. Total Validation Data

Problem solving-based thematic e-modules

\begin{tabular}{cc}
\hline Aspect & Validator \\
\hline contents & $93 \%$ \\
\hline design & $91 \%$ \\
\hline total & 184 \\
\hline mean & 92 \\
\hline
\end{tabular}

The total results of experts in assessing student e-modules are $92 \%$ with very valid criteria.

\section{DISCUSSION}

Based on the results of expert data, it was stated that problem-solving-based thematic e-modules were developed according to the needs in the module and could be used in learning. The components and content in the module have been adapted to thematic and problem solving-based learning. Total validation of e-modules obtained $92 \%$ with very valid criteria.

The components in the developed module include Mapping Basic Competencies, Mapping Indicators, Learning Objectives, Let's Read, Let's Tell a Story, Let's Observe, Let's Discuss, Let's Write, Let's Practice, Conclusions, test questions. The components in the module at least contain an introduction, learning activities, and bibliography(Muslich, 2010; Parmin \& Peniati, 2012). Problem-solving-based thematic e-modules also present material, questions that provide problems so that students can think critically(Erol \& Kurt, 2017; Moore-Russo \& Demler, 2018; Silvia, Risnita, \& Syaiful, 2015). Problems are presented contextually so that students can analyze, collect data from various sources or observations(Chang et al., 2020; Llera \& Newman, 2020)

The results of total validation of e-modules are $94 \%$ with very valid criteria. In terms of design, the module is packaged and designed according to student development. Because, 3rd-grade students still like colorful designs(Mufliharsi \& Sulhan, 2020; Roskos, Brueck, \& Lenhart, 2017). 


\section{CONCLUSION}

The results of this study are in form of problem-solving-based thematic emodules. Systematic module presentation was consisted of Mapping Basic Competencies, Mapping Indicators, Learning Objectives, Let's Read, Let's Tell a Story, Let's Observe, Let's Discuss, Let's Write, Let's Practice, Conclusion. The results of material validation are $93 \%$ in the very valid category and $91 \%$ of media validation results are in the very valid category so that they can be used in learning.

\section{REFERENCES}

Akbar, S., \& Sutama, I. W. (2010). Pengembangan Model Pembelajaran Tematik untuk Kelas 1 dan Kelas 2 Sekolah Dasar Sa'dun, 17(April), 32-40.

Caskurlu, S., Richardson, J. C., Maeda, Y., \& Kozan, K. (2021). The qualitative evidence behind the factors impacting online learning experiences as informed by the community of inquiry framework: A thematic synthesis. Computers and Education, $\quad$ 165(July 2020), 104111. https://doi.org/10.1016/j.compedu.2020.104111

Chang, E. C., Liu, J., Yi, S., Jiang, X., Li, Q., Wang, R., ... Chang, O. D. (2020). Loneliness, social problem solving, and negative affective symptoms: Negative problem orientation as a key mechanism. Personality and Individual Differences, 167(July), 110235. https://doi.org/10.1016/j.paid.2020.110235

Chrisyarani, D. D., \& Akbar, S. (2017). Modul komik tematik berbasis. Sekolah Dasar: Kajian Teori Dan Praktik Pendidikan, Tahun 26 N, 175-181. https://doi.org/http://dx.doi.org/10.17977/um009v26i22017p175

de Hei, M., Strijbos, J. W., Sjoer, E., \& Admiraal, W. (2016). Thematic review of approaches to design group learning activities in higher education: The development of a comprehensive framework. Educational Research Review, 18, 33-45. https://doi.org/10.1016/j.edurev.2016.01.001

Erick Suryadi, P. G., Agustini, K., \& Sugihartini, N. (2019). Pengaruh E-Modul Berbasis Model Pembelajaran Project Based Learning Pada Mata Pelajaran 
Videografi Terhadap Hasil Belajar Siswa Kelas Xi Desain Komunikasi Visual Di Smk Negeri 1 Sukasada. Jurnal Nasional Pendidikan Teknik Informatika (JANAPATI), 7(3), 302. https://doi.org/10.23887/janapati.v7i3.13433

Erol, O., \& Kurt, A. A. (2017). The effects of teaching programming with scratch on pre-service information technology teachers' motivation and achievement. Computers in Human Behavior, 77, 11-18. https://doi.org/10.1016/j.chb.2017.08.017

Goyena, R., \& Fallis, A. . (2019). 済無No Title No Title. Journal of Chemical Information and Modeling, 53(9), 1689-1699. https://doi.org/10.1017/CBO9781107415324.004

Hong, J. C., Lee, Y. F., \& Ye, J. H. (2021). Procrastination predicts online selfregulated learning and online learning ineffectiveness during the coronavirus lockdown. Personality and Individual Differences, 174(October 2020), 110673. https://doi.org/10.1016/j.paid.2021.110673

Kemendikbud. (2020). Surat Edaran Nomor 3 Tahun 2020 tentang Pencegahan COVID-19 pada Satuan Pendidikan. Jakarta.

Kurniawan, G. E. (2019). Pengembangan Modul Pembelajaran Berbasis Model Problem Solving Untuk Meningkatkan High Order Thinking Skill Pada Pelajaran Ipa Pokok Bahasan Fluida Statis Siswa Kelas Viii Smp N 7 Cirebon Tahun Ajaran 2018/2019. Mangifera Edu, 63-72. https://doi.org/10.31943/mangiferaedu.v4i1.531

Llera, S. J., \& Newman, M. G. (2020). Worry impairs the problem-solving process: Results from an experimental study. Behaviour Research and Therapy, 135(March), 103759. https://doi.org/10.1016/j.brat.2020.103759

Montag-Smit, T., \& Maertz, C. P. (2017). Searching outside the box in creative problem solving: The role of creative thinking skills and domain knowledge. Journal of Business Research, 81(July), 1-10. https://doi.org/10.1016/j.jbusres.2017.07.021 
Moore-Russo, D., \& Demler, E. L. (2018). Linking Mathematical Creativity to Problem Solving: Views from the Field, 321-345. https://doi.org/10.1007/978-3-31999861-9_14

Mudiono, A., Akbar, S., Dwi Yasa, A., \& Delawanti Chrisyarani, D. (2017). Developing Multiple Intelligences-Based Thematic Comic Module. Pancaran Pendidikan, 6(4), 115-124. https://doi.org/10.25037/pancaran.v6i4.111

Mufliharsi, R., \& Sulhan, M. (2020). Desain Pengembangan Bahan Ajar Micro Teaching: Analisis Kebutuhan, 7(1), 13-20.

Munir, M. T., Baroutian, S., Young, B. R., \& Carter, S. (2018). Flipped classroom with cooperative learning as a cornerstone. Education for Chemical Engineers, 23, 2533. https://doi.org/10.1016/j.ece.2018.05.001

Muslich, M. (2010). Text Book Writing, Dasar-dasar Pemahaman, Penulisan dan Pemakaian Buku Teks. Yogyakarta: Arruzz Media.

Parmin, \& Peniati, E. (2012). Pengembangan modul mata kuliah strategi belajar mengajar ipa berbasis hasil penelitian pembelajaran. Jurnal Pendidikan IPA Indonesia, 1(1), 8-15. https://doi.org/10.15294/jpii.v1i1.2006

Roskos, K., Brueck, J., \& Lenhart, L. (2017). An analysis of e-book learning platforms: Affordances, architecture, functionality and analytics. International Journal of Child-Computer Interaction, 12, 37-45. https://doi.org/10.1016/j.ijcci.2017.01.003

Silvia, F., Risnita, R., \& Syaiful, S. (2015). Pengembangan Rubrik Keterampilan Berpikir Kreatif dalam Memecahkan Masalah Matematika Siswa Kelas VIII SMP Attaufiq Jambi. Edu-Sains: Jurnal Pendidikan Matematika Dan Ilmu Pengetahuan Alam, 4(1). https://doi.org/10.22437/jmpmipa.v4i1.2363

Sugihartini, N., \& Jayanta, N. L. (2017). Pengembangan E-Modul Mata Kuliah Strategi Pembelajaran. Jurnal Pendidikan Teknologi Dan Kejuruan, 14(2), 221-230. https://doi.org/10.23887/jptk-undiksha.v14i2.11830 
Troseth, G. L., \& Strouse, G. A. (2017). Designing and using digital books for learning: The informative case of young children and video. International Journal of ChildComputer Interaction, 12, 3-7. https://doi.org/10.1016/j.ijcci.2016.12.002

UNESCO. (2020). 290 million students out of school due to COVID-19. Retrieved from https://en.unesco.org/news/290-\%0Amillion-students-out-school-due\%02covid-19unesco-releases-first\%02global-numbers-and-mobilizes

Utari, U., Degeng, I. N. S., \& Akbar, S. (2016). Pembelajaran Tematik Berbasis Kearifan Lokal Di Sekolah Dasar Dalam Menghadapi Masyarakat Ekonomi Asean (MEA). Jurnal Teori Dan Praksis Pembelajaran IPS, 1(1), 39-44. https://doi.org/10.17977/um022v1i12016p039

Vu, C.-T., Hoang, A.-D., Than, V.-Q., Nguyen, M.-T., Dinh, V.-H., Le, Q.-A. T., ... Nguyen, Y.-C. (2020). Dataset of Vietnamese teachers' perspectives and perceived support during the COVID-19 pandemic. Data in Brief, 105788. https://doi.org/10.1016/j.dib.2020.105788 